\title{
Ekstrak Angkak dan Bekatul untuk Mencegah Peroksidasi Lipid Tikus Spague-Dawley Hiperglikemik
}

\section{Angkak and Rice Bran Extract to Prevent Lipid Peroxidation in Spague-Dawley Rats Hyperglycemic}

Hasim Hasim¹, Moh Asroriy Nuris¹, Agus Setyono², Eka Nurul Qomaliyah1, Didah Nur Faridah³

${ }_{1}^{1}$ Departemen Biokimia, Fakultas Matematika dan IImu Pengetahuan Alam, Institut Pertanian Bogor, Bogor

2Departemen Klinik, Reproduksi dan Patologi, Fakultas Kedokteran Hewan, Institut Pertanian Bogor, Bogor

${ }^{3}$ Departemen Ilmu dan Teknologi Pangan, Fakultas Teknologi Pertanian, Institut Pertanian Bogor, Bogor

*Korespondensi (hasim@apps.ipb.ac.id)

Artikel ini dikirim pada tanggal 10 Oktober 2019 dan dinyatakan diterima tanggal 25 April 2020. Artikel ini juga dipublikasi secara online melalui https://ejournal2.undip.ac.id/index.php/jatp. Hak cipta dilindungi undang-undang. Dilarang diperbanyak untuk tujuan komersial.

Diproduksi oleh Indonesian Food Technologists $® @ 2020$

\begin{abstract}
Abstrak
Angkak dan bekatul merupakan pangan fungsional yang berpotensi sebagai agen terapi untuk mengendalikan gula darah, dikarenakan kandungan antioksidan alaminya. Tujuan penelitian adalah untuk mengevaluasi pengaruh campuran ekstrak angkak dan bekatul dalam menghambat peroksidasi lipid serta efeknya terhadap organ pankreas, hati dan ginjal tikus hiperglikemik secara histopatologi. Tikus dibagi ke dalam 7 kelompok yaitu kelompok kontrol normal, kontrol negatif, kontrol positif, formulasi ekstrak angkak bekatul kelompok I, II, III dan IV (20:1400, 40:700, 30:1050, dan 60:2100 mg/kg BB). Parameter pengujian yang dilakukan adalah konsentrasi malondialdehid (MDA) dan aktivitas enzim aminotransferase (ALT/AST) serum darah tikus dan histopatologi organ pankreas, hati dan ginjal. Campuran terbaik dalam menghambat pembentukan MDA dan peningkatan enzim ALT/AST adalah kelompok III dengan konsentrasi MDA $(3,31 \pm 0,53 \mathrm{nmol} / \mathrm{ml})$ dan aktivitas enzim ALT $(35,80 \pm 5,63 \mathrm{U} / \mathrm{l})$ tidak berbeda nyata dengan kontrol normal $(4,85 \pm 2,32 \mathrm{nmol} / \mathrm{ml})$ dan $(27,85 \pm 8,13)$, sementara aktivitas enzim AST $(67,221 \pm 16,05)$ mengalami penurunan namun berbeda nyata dengan kontrol normal $(4,365 \pm 0,00)$. Kondisi histopatologi organ pankreas, hati, dan ginjal tikus semua kelompok perlakuan menunjukkan kemampuan dalam memperbaiki kerusakan organ. Kesimpulannya, campuran angkak dan bekatul 30:1050 mg/kg BB memiliki kemampuan terbaik dalam meghambat peroksidan lipid.
\end{abstract}

Kata kunci: aminotransferase, histopatologi, hiperglikemia, malondialdehid, peroksidasi lipid

\begin{abstract}
Angkak and rice bran is a functional food that has potential as a therapeutic agent to control blood sugar. This potential is due to the content of natural antioxidants in red yeast rice and rice bran. The objective of this research was to evaluate the effect of angkak and rice bran extract as lipid peroxidation inhibition. The effect on the pancreatic, liver and kidney organs in hyperglycemic rats by histopatological study was also analyzed. Rats were divided into 7 groups namely normal control group, negative control, positive control, rice bran extract formulation on gorup I, II, III, IV (20: 1400, 40: 700, 30: 1050, and 60: $2100 \mathrm{mg} / \mathrm{kg} \mathrm{BW).} \mathrm{The} \mathrm{analysis} \mathrm{parameters} \mathrm{carried} \mathrm{out} \mathrm{were} \mathrm{the} \mathrm{concentration}$ of malondialdehyde (MDA), the activity of the serum alanine/aspartat aminotransferase (ALT/AST) enzymes and rat histopathology of pancreatic, liver and kidney organs. The best mixture of angkak and rice bran to inhibit the formation of MDA and increase the ALT/AST enzyme was group III with MDA concentration $(3,31 \pm 0,53 \mathrm{nmol} / \mathrm{ml})$ and $A L T$ enzyme activity $(35,80 \pm 5,63 \mathrm{U} / \mathrm{l})$ was not significantly different from normal control $(4,85 \pm 2,32 \mathrm{nmol} / \mathrm{ml})$ and $(27,85 \pm 8,13)$, while the enzyme activity of AST $(67,221 \pm 16,05)$ decreased but was significantly different from normal controls $(4,365 \pm 0,00)$. Histopathological conditions of pancreatic, liver, and kidney organs of rats in all treatment groups showed the ability to repair damaged organs. In conclusion, the mixture of red yeast rice and rice bran 30:1050 $\mathrm{mg} / \mathrm{kg} \mathrm{BW}$ had the best ability to inhibit lipid antioxidants.
\end{abstract}

Keywords: aminotransferase, histopathology, hyperglycemia, malondialdehyde, lipid peroxidation.

\section{Pendahuluan}

Angkak maupun bekatul merupakan produk pangan fungsional yang mempunyai potensi sebagai antidiabetes (Boonloh et al., 2015; Justo et al., 2013; Kaup et al., 2013). Angkak atau red koji merupakan hasil fermentasi beras dengan menggunakan kapang dari famili Monascus terutama Monascus purpureus (Kasim et al., 2006). Angkak adalah makanan fermentasi yang berasal dari China dan sering digunakan sebagai bahan alami pewarna dan pengawet makanan seperti pada produk soy been cheese, daging dan red wine (Akihisa et al., 2005), sedangkan bekatul merupakan hasil samping dari proses penggilingan beras yang kaya nutrisi dan senyawa aktif biologis (Boonloh et al., 2015). Diabetes mellitus ditandai dengan kondisi hiperglikemia dan merupakan penyebab utama mortalitas dan morbiditas di seluruh dunia (Kong et al., 2017). Berdasarkan data World Health Organization (WHO), diperkirakan jumlah pasien diabetes mellitus tipe dua didunia pada tahun 2030 akan lebih dari 300 juta orang (Pathel et al., 2012). Lebih lanjut, berdasarkan International Diabetes Federation (IDF) pada tahun 2017 Indonesia menempati posisi ke tujuh di dunia, sebagai negara dengan jumlah penderita diabetes sebesar 10,7 
juta jiwa, dengan perkiraan jumlah penderita meningkat menjadi 13,7 juta jiwa pada tahun 2030. Kondisi hiperglikemia yang tidak terkontrol pada penderita diabetes mendorong pembentukan radikal bebas melalui pembentukan spesies oksigen reaktif (ROS), oleh karena adanya glikasi protein non-enzimatik, oksidasi glukosa, dan peningkatan peroksidasi lipid yang menyebabkan kerusakan enzim, resistensi insulin, dan stress oksidatif (Maritim et al., 2003).

Radikal bebas yang terbentuk, rentan menyerang asam lemak tak jenuh ganda dalam sel menghasilkan produk radikal lipid yang reaktif dan beracun, sehingga memicu terjadinya komplikasi diabetes (Matough et al., 2012) yang dapat berakibat pada terjadinya risiko penyakit vaskular sistemik (percepatan aterosklerosis), jantung, mikrovaskular pada mata, retinopati, kerusakan ginjal dan neuropati diabetik (Halliwell and Gutteridge, 1999). Salah satu biomarker kritis stress oksidatif adalah tingginya peroksidasi lipid (Pasaouglu et al., 2004). Malondialdehyde (MDA) merupakan produk akhir dari peroksidasi lipid yang dapat diamati melalui reaksi dengan tiobarbiturat (Esterbauer et al., 1991).

Potensi antidiabetes pada angkak dikarenakan peranannya sebagai antioksidan yang dapat menstimulasi regenerasi sel $\beta$ pankreas berasal dari ankaflavin, monaskin, $\gamma$-aminobutyric acid (Shi and Pan, 2010). Pada bekatul, komponen yang berperan sebagai antioksidan adalah $\beta$-sitosterol, $\gamma$-orizanol, tocotrienol, tokoferol, squalene, oryzanol dan inositol ( $\mathrm{Xu}$ and Godbee, 1999). Angkak dan bekatul juga memiliki potensi menurunkan kadar enzim alanin aminotransferase (ALT) dan aspartat aminotransferase (AST) yang menjadi penanda kerusakan hati (Antula et al., 2019; Wahyuningsih et al., 2019). Ketika sel-sel hati rusak oleh karena oksidasi lemak dan sel menjadi apoptosis atau nekrosis, maka kedua enzim ini dapat bocor ke peredaran darah sebagai akibat adanya peningkatan permeabilitas membran (Li et al., 2012). Adanya kerusakan ini dapat diperparah oleh senyawa antioksidan endogen yang tidak seimbang dengan adanya pembentukan ROS, sehingga dibutuhkan antioksidan eksogen yang berasal dari makanan.

Pengembangan penelitian angkak ataupun bekatul sebagai pangan fungsional produk herbal antidiabetes telah dibuktikan baik secara in vitro dan in vivo (Posuwan et al. 2013, Boue et al., 2016). Berdasarkan penelitian Rajasekran et al. (2009) diperoleh bahwa terjadi penurunan glukosa darah pada tikus setelah perlakuan ekstrak air angkak. Berdasarkan penelitian Chen and Liu (2006) dilaporkan bahwa angkak dapat menjadi bahan panganan yang menstimulasi peningkatan insulin sehingga dapat mencegah diabetes tipe 2 , penelitian ini dilakukan pada tikus dengan pemberian pakan menggunakan angkak 100 dan 150 mg/kg, kemudian darah tikus diambil untuk mengukur konsentrasi glukosa plasma menggunakan komersial kit dan plasma insulin dianalisis menggunakan ELISA kit, diperoleh bahwa terdapat penurunan konsentrasi plasma gula dan meningkatnya sekresi insulin yang dapat dipengaruhi oleh aktivasi reseptor M3 muskarinik pada sel $\beta$-pankreas. Sementara berdasarkan penelitian Aalim et al. (2018) bekatul menunjukkan potensi antidiabetes melalui pengamatan penghambatan enzim alfa glukosidase. Penjabaran lanjut peranan bekatul dalam penelitian Jung et al. (2015) melalui pengukuran terhadap tingkat Myc-tagged GLUT-4 secara kalorimetri antibody-coupled menggunakan sel L6 yang diberi perlakuan dengan bekatul. Bekatul mengandung y-orizanol yang berperan megontrol hiperglikemia melalui stimulasi translokasi GLUT-4 dari sitosol ke permukaan sel sehingga uptake glukosa ke dalam sel dapat dilakukan. Gabungan dari angkak dan bekatul berdasarkan hasil penelitian Govindarajan and Vellingiri 2016, diperoleh bahwa kombinasi antara angkak dan bekatul menunjukkan kadar kolesterol serum, trigliserida dan MDA yang jauh lebih rendah pada tikus setelah perlakuan selama sebulan. Perkembangan penelitian meggunakan angkak, bekatul serta kombinasi keduanya dalam penelitian antidiabetes serta diet hiperkolesterol cukup banyak dilaporkan, namun efek dari penggunaan campuran angkak dan bekatul pada kerja organ pankreas, hati dan ginjal tikus yang diamati secara mikroskopik belum pernah dilaporkan. Oleh karena itu, penelitian ini bertujuan untuk mempelajari efektivitas campuran angkak dan bekatul dalam mencegah peroksidasi lipid dan efeknya terhadap organ pankreas, hati dan ginjal hewan coba hiperglikemik secara histopatologi

\section{Materi dan Metode \\ Materi}

Bahan utama yang digunakan yaitu angkak yang berasal dari pasar tradisional Bogor dan bekatul dari jenis padi pandan wangi yang diperoleh dari penggilingan padi Situ Gede, Bogor. Bekatul dan angkak langsung dilakukan preparasi di laboratorium sebelum digunakan. Bahan-bahan analisis yang digunakan yaitu n-butanol (Merck, Jerman)1,1,3,3-tetrametoksipropana standar (TMP) (Sigma-aldrich, USA), piridin (Merck, Jerman), asam asetat glasial (Merck, Jerman), asam tiobarbiturat TBA (Merck, Jerman), $\mathrm{H}_{2} \mathrm{SO}_{4}$ pekat (Sigmaaldrich, USA), pereaksi ALT/AST (Sigma-aldrich, USA) dan (Kit ReiGed, Turkey) (REF ALT:GPT-11100; AST:GOT-11100), aloksan monohidrat (Sigma-Aldrich, USA), $\mathrm{NaCl}$ 0,9\% (Otsuka, Indonesia), pewarna rutin ematoksilin dan eosin (sigma-aldrich, USA), alkohol $70 \%$, etanol (Emsure, Jerman), xilol (Merck, Jerman), parafin cair (Merck, Jerman), ketamine (Sigma-aldrich, USA), xylazine (Sigma-aldrich, USA), buffer neutral formaline (Merck, Jerman), glibenklamid (Indofarma, Indonesia) dan tikus putih galur Sprague-Dawley berusia 8 minggu dengan rata-rata bobot badan 180-220 gram yang diperoleh dari Fakultas Kedokteran Hewan IPB, dan pakan standar (Bravo Hi-Provit, Indonesia).

Alat-alat yang digunakan yaitu neraca analitik (OHAUS GA200, USA), tabung Eppendorf (Eppendorf, Jerman), tabung sentrifus (Eppendorf, Jerman), penangas air (Memmert WNE 10, Jerman), mikroskop (Olympus, Jepang), kuvet kaca, autoklaf (ALP MC40, Jepang), freezer, vortex (Genie G5-60E), sonikator (Bransonic, USA), sonde oral, kandang tikus, alat bedah 
hewan coba, timbangan tikus, pipet mikro (Eppendorf, Jerman), syringe OneMed, glukometer (OneTouch UltraEasy, Inggris), lancets, strip glukosa (OneTouch Ultra, Inggris), automatic tissue processor (Thermo Scientific Excelsior, USA), frozen tissue embedding machine (Thermofisher histostar, USA), cover glass, sentrifus (Beckman model J2-21, USA), mikrosentrifus (Damon/IEC Divission, Massachusetts, USA ), software SPSS 2.1 dan spektrofotometer UV-Vis (Thermo Electron Corporation model Genesys 10, USA).

\section{Preparasi Angkak dan Bekatul}

Sampel angkak dan bekatul dihaluskan menggunakan blender ukuran 40 mesh. Sampel angkak dikeringkan dalam oven pada suhu $50^{\circ} \mathrm{C}$ selama 6 jam, sedangkan sampel bekatul dikeringkan pada suhu $130^{\circ} \mathrm{C}$ selama 90 detik. Sampel yang digunakan memiliki kadar air $<10 \%$. Ekstraksi secara maserasi menggunakan pelarut air selama 3 jam dengan pengadukan $130 \mathrm{rpm}$. Sebanyak $40 \mathrm{~g}$ serbuk angkak dalam $400 \mathrm{ml}$ (1:10) dan $40 \mathrm{~g}$ serbuk bekatul dalam 160 $\mathrm{ml}$ (1:4). Filtrat diuapkan menggunakan rotary evaporator pada suhu $50^{\circ} \mathrm{C}$ dengan kecepatan $75 \mathrm{rpm}$ hingga diperoleh ekstrak air angkak dan bekatul pekat.

\section{Induksi Diabetes Tikus dan Perlakuan}

Tikus diadaptasi selama 12 hari untuk menyeragamkan pola hidup dan mencegah tikus stress. Selama masa adaptasi, tikus diberi pakan standar sebanyak $20 \mathrm{~g}$ per ekor per hari dan air minum secara ad libitum. Tikus dibagi ke dalam 7 kelompok, yaitu kelompok kontrol normal (NO) hanya pemberian pakan standar sampai selesai pengujian, kelompok kontrol negatif (NE) hanya diinduksi aloksan tanpa pemberian obat ataupun ekstrak, kelompok kontrol positif (PO) diberi obat glibenklamid, kelompok perlakuan diinduksi aloksan serta diberi campuran ekstrak air dari angkak bekatul, dengan rincian sebagai berikut: kelompok perlakuan I (1:2) sebanyak 20:1400 mg/kg BB, kelompok perlakuan II campuran ekstrak air angkak bekatul (2:1) sebanyak 40:700 mg/kg BB, kelompok perlakuan III ekstrak air angkak bekatul (1:1; konsentrasi rendah) sebanyak 30:1050 mg/kg BB, dan kelompok perlakuan formulasi ekstrak air angkak bekatul (1:1; konsentrasi tinggi) sebanyak 60:2100 mg/kg BB. Semua kelompok kecuali kelompok NO diinduksi aloksan dengan dosis $150 \mathrm{mg} / \mathrm{kg}$ bb dalam $1 \mathrm{ml}$ secara intraperitoneal. Selanjutnya, tikus di puasakan 16 jam dan dinekropsi untuk diambil organ pankreas, hati, ginjal, dan darah sampelnya. Organ yang digunakan dalam analisis MDA, disimpan pada larutan $\mathrm{NaCl}$ fisiologis dan dibekukan pada $-20^{\circ} \mathrm{C}$, sedangkan organ yang dianalisis histopatologi, disimpan dalam larutan buffer neutral formaline $10 \%$ (BNF).

\section{Pengukuran Konsentrasi MDA}

Pemisahan serum darah berdasarkan Washington and Hoosier (2012) darah dikumpulkan dalam tabung Eppendorf. Pemisahan dilakukan dengan sentrifugasi pada kecepatan $3000 \mathrm{rpm}$ selama 15 menit untuk memperoleh serum. Dilanjutkan, analisis konsentrasi MDA serum darah berdasarkan Yagi (1987). Sebanyak $0,2 \mathrm{ml}$ serum darah ditambah dengan $1,2 \mathrm{ml}$ $\mathrm{H}_{2} \mathrm{SO}_{4} 0,083 \mathrm{~N}$, diinkubasi suhu ruang selama 10 menit, lalu ditambahkan $0,15 \mathrm{ml}$ asam fosfotungstat $10 \%$, dan inkubasi lagi selama 5 menit. Hasil pencampuran tersebut kemudian disentrifugasi pada kecepatan 3000 rpm selama 20 menit. Bagian pelet dilarutkan dalam 0,5 $\mathrm{ml}$ akuades dengan bantuan vortex, kemudian dipindahkan kedalam tabung sentrifus. Selanjutnya, pada pelet ditambahkan 0,5 $\mathrm{ml}$ TBA $1 \%$ dalam asam asetat $50 \%$. Larutan lalu dipanaskan pada suhu $95^{\circ} \mathrm{C}$ selama 60 menit dan ditambah $2,5 \mathrm{ml}$ (n-butanol : piridin), kemudian disentrifugasi pada $3000 \mathrm{rpm}$ selama 15 menit. Serapannya diukur dengan spektrofotometer UV-Vis pada panjang gelombang $(\lambda) 532 \mathrm{~nm}$. Perhitungan kadar MDA diperoleh dengan membandingkan absorbansi dengan kurva standar tetraetoksipropan menggunakan persamaan $Y=a X+b$. Dimana a adalah kemiringan garis $Y$ dan $b$ adalah nilai konstanta atau interseptor. Maka perhitungan kadar MDA yakni absorbansi dikurangi interseptor dibagi nilai kemiringan garis y dikali faktor pengenceran dibagi volume sampel.

\section{Pengukuran Aktivititas Enzim AST dan ALT}

Tingkat cidera hati dihitung berdasarkan enzim ALT dan AST serum darah berdasarkan IFCC (1986) menggunakan kit diagnosa komersial (ReiGed kit, Turkey) pada panjang gelombang $340 \mathrm{~nm}$. Nilai absorbansi dicatat setiap menit selama 3 menit, sehingga diperoleh 3 nilai absorbansi. Aktivitas enzim AST dan ALT dinyatakan dalam U/l. Aktivitas enzim AST diperoleh melalui perhitungan rata-rata absorbansi per menit dikali faktor perhitungan sebesar 1768. Sedangkan aktivitas enzim ALT diperoleh melalui perhitungan rata-rata absorbansi per menit dikali faktor perhitungan sebesar 1746 .

\section{Analisis Histopatologi Organ}

Analisis histopatologi organ dilakukan berdasarkan Masjedi et al. (2013). Organ pankreas, ginjal, jantung dan hati dibiopsi untuk pemeriksaan histologi. Organ pankreas, hati dan ginjal yang diambil direndam pada larutan BNF 10\% dengan $\mathrm{pH}$ berkisar $6,5-7,5$. Perbandingan organ dan larutan adalah 1:10 dan disimpan hingga jaringan fiksatif, sampel didehidrasi, ditanam dalam paraffin. Preparat organ dibuat setebal 0,3-0,5 $\mathrm{mm}$ dan diwarnai dengan hematoksilin dan eosin. Preparat diamati dengan mikroskop cahaya berkamera. Masing-masing preparat diamati pola susunan dan bentuk selnya.

\section{Analisis Statistika}

Penelitian ini menggunakan rancangan acak lengkap (RAL). Analisis statistik terhadap konsentrasi MDA serum dan aktivitas enzim aminotransferase tikus dilakukan menggunakan metode One-way ANOVA (analysis of variance) dengan taraf nyata 0,05 dan diuji lanjut menggunakan uji Duncan. Data hasil analisis dinyatakan berbeda nyata apabila $p<0,05$ dan tidak berbeda nyata apabila $p>0,05$. Analisis data dilakukan 
menggunakan program perangkat lunak IBM SPSS Statistics 21 for Windows.

\section{Hasil dan Pembahasan}

Konsentrasi Malonilaldehid Serum Darah

MDA adalah suatu aldehida 3-karbon, memiliki berat molekul rendah yang dihasilkan oleh reaksi rantai radikal bebas dengan lipid tak jenuh pada membran sel (Grotto et al., 2009). MDA menjadi hasil peroksidasi lipid yang paling mutagenik (Esterbaue et al., 1990). Pengukuran kadar MDA menjadi biomarker populer untuk peroksidasi lipid tak jenuh asam lemak omega-3 dan omega- 6 secara klinis yang mudah bereaksi dengan asam tiobarbiturat (TBA) (Giera et al., 2012). Prinsip pengukuran kadar MDA serum darah dengan TBA yaitu terjadinya reaksi kompleks antara MDA-TBA, setelah penambahan TBA pada sampel serum darah dan dibantu proses pemanasan pada $\mathrm{pH}$ asam (Lykkesfeldt, 2007).

Tabel 1. Konsentrasi MDA serum darah pada setiap kelompok percobaan

\begin{tabular}{lc}
\hline Kelompok & {$[\mathrm{MDA}](\mathrm{nmol} / \mathrm{ml})$} \\
\hline Kelompok kontrol normal (NO) & $4,855 \pm 2,318^{\mathrm{a}}$ \\
Kelompok kontrol positif (PO) & $7,206 \pm 0,676^{\mathrm{ab}}$ \\
Kelompok kontrol negatif (NE) & $11,815 \pm 4,948^{\mathrm{c}}$ \\
Kelompok perlakuan I & $5,517 \pm 0,409^{\mathrm{ab}}$ \\
Kelompok perlakuan II & $9,739 \pm 2,764^{\mathrm{bc}}$ \\
Kelompok perlakuan III & $3,313 \pm 0,529^{\mathrm{a}}$ \\
Kelompok perlakuan IV & $4,052 \pm 1,086^{\mathrm{a}}$ \\
\hline
\end{tabular}

Keterangan: huruf berbeda di belakang konsentrasi MDA

menunjukkan perbedaan signifikan $(p<0,05)$

Kondisi hiperglikemik mendorong terjadinya peningkatan kadar MDA serum darah akibat peningkatan stress oksidatif yang menghasilkan ketidakseimbangan antara radikal bebas dengan sistem antioksidan endogen tubuh. Hasil pengukuran konsentrasi MDA serum darah dari ke 5 kelompok perlakuan formulasi angkak-bekatul diukur pada hari ke21 setelah induksi, tertera pada Tabel 1. Suplementasi angkak dan bekatul kelompok I, III dan IV secara signifikan $(p<0,05)$ menurunkan konsentrasi MDA serum. Konsentrasi MDA kelompok kontrol negatif dan kelompok perlakuan II tidak menunjukkan perbedaan signifikan. Kelompok perlakuan III campuran angkakbekatul (30:1050 mg/kg BB) memiliki kemampuan penurunan konsentrasi MDA terbaik dan tidak berbeda nyata dengan kelompok kontrol normal (NO). Hal ini dikarenakan kelompok perlakuan III dengan campuran angkak-bekatul 30:1050 mg/kg BB memiliki aktivitas antioksidan tertinggi berdasarkan hasil penelitian sebelumnya, IC 50 DPPH $(5,95 \pm 5,53 \mu \mathrm{g} / \mathrm{ml})$.

Penurunan konsentrasi MDA serum tikus yang diinduksi angkak-bekatul dibandingkan kelompok kontrol negatif disebabkan oleh adanya senyawa aktif yang berperan sebagai antioksidan seperti likopen, tokoferol, tokotrienol, orizanol, dan antosianin (Garcia, 2007; Damayanthi et al., 2010). Penelitian lainnya menunjukkan bahwa angkak dan bekatul mengandung ankaflavin, monaskin, $\gamma$-aminobutyric acid, komponen $\beta$ sitosterol, $\gamma$-orizanol, tocotrienol pada angkak dan bekatul yang dapat meningkatkan sekresi dan sensitifitas insulin (Chen and Cheg, 2006; Shi and Pan, 2010). Selain itu, senyawa $\beta$-sitosterol secara spesifik berperan dalam penangkapan produk lipid peroksidasi pada tikus hiperglikemia (Baskar et al., 2012). Komponen bioaktif antioksidan dalam angkak dan bekatul inilah yang berperan penting dalam menghentikan reaksi berantai dari proses peroksidasi lipid.

\section{Aktivitas Enzim Aminotransferase Serum Darah}

Perubahan fungsi hepar secara kuantitatif dapat diukur melalui parameter AST dan ALT serum darah tikus. ALT dan AST dapat meningkat ketika terjadi nekrosis sel hati (Jaeschk, 2010) yang menandakan kerusakan hati. Kerusakan sel hati diinisiasi oleh kerusakan membran sel antara lain perubahan fluiditas, struktur, dan fungsi membran sel oleh radikal bebas reaktif (Catala, 2010). Efek komplikasi dari diabetes yaitu meningkatkan proses glukoneogenesis, ketogenesis dan stress oksidatif peroksidasi lipid yang berkontribusi dalam meningkatkan jumlah kerja enzim AST dan ALT (Brouns, 2018; Cui et al., 2014).

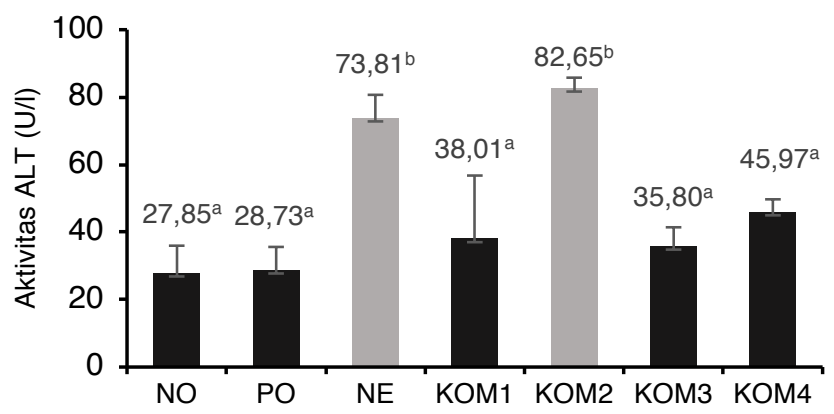

Figur 1. Aktivitas enzim ALT serum darah tikus

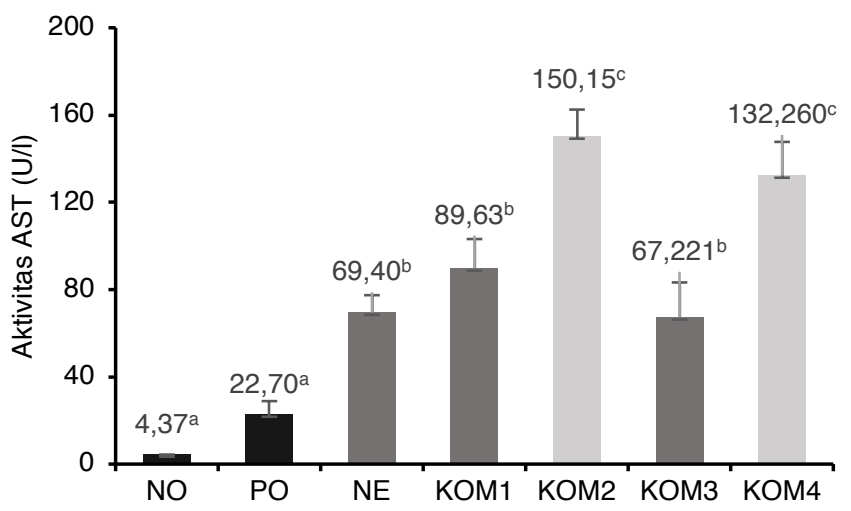

Figur 2. Aktivitas enzim AST serum darah tikus Keterangan (untuk Fig. 1 dan 2):

Huruf yang berbeda menunjukkan perbedaan signifikan $(p<0,05)$. Kelompok kontrol normal (NO), Kelompok kontrol positif (PO), Kelompok kontrol negatif (NE), Kelompok perlakuan I (KOM1), Kelompok perlakuan II (KOM2), Kelompok perlakuan III (KOM3), Kelompok perlakuan IV (KOM4).

Pada kondisi normal, aktivitas ALT dan AST tikus jantan Sprague-Dawley yang berusia 8-16 minggu masing-masing sebesar 18-45 dan 74-143 U/I (Giknis and Clifford, 2008). Hasil pengukuran rata-rata enzim ALT setiap kelompok ditunjukkan dalam Figur 1. 
Pengukuran rata-rata enzim ALT kelompok kontrol sebesar 27,85 U/l dan kelompok kontrol positif sebesar $28,73 \mathrm{U} / \mathrm{l}$, berbeda nyata $(\mathrm{p}<0,05)$ dengan kelompok kontrol negatif dengan induksi aloksan sebesar 73,81 U/I, dengan peningkatan sebesar 165,08\%. Hal ini menandakan bahwa pemberian aloksan dapat menyebabkan kerusakan hati yang ditandai dengan peningkatan aktivitas enzim ALT/AST serum secara signifikan. Senyawa aloksan merupakan salah satu zat diabetogenik yang bersifat toksik terutama terhadap sel $\beta$ pankreas. Zat aloksan yang bersifat toksik dapat merusak organ hati melalui kerusakan permeabilitas membran selnya sehingga dapat meningkatnya transaminase, kadar ALT AST pada serum darah (Dahech et al., 2011; Sebai et al., 2014).

Seluruh kelompok perlakuan yaitu dengan pemberian campuran angkak-bekatul menunjukkan rata-rata aktivitas enzim ALT serum lebih rendah dari kelompok negatif dan berbeda nyata $(p<0,05)$, kecuali kelompok perlakuan II. Rata-rata penurunan aktivitas enzim ALT pada kelompok I, III, dan IV secara berturutturut sebesar 48,50, 51,50, dan 37,72\% lebih rendah dibandingkan dengan kelompok kontrol negatif. Data ini menunjukkan bahwa kelompok perlakuan III (30:1050 $\mathrm{mg} / \mathrm{kg} \mathrm{BB}$ ) memiliki penurunan aktivitas enzim ALT tertinggi.

Hasil pengukuran rata-rata aktivitas enzim AST serum menunjukkan bahwa rata-rata aktivitas enzim AST dari kelompok kontrol adalah sebesar 4,37 U/l dan kelompok kontrol positif glibenklamid adalah sebesar $22,70 \mathrm{U} / \mathrm{l}$, berbeda nyata $(\mathrm{p}<0,05)$ dengan kelompok kontrol negatif yang diinduksi aloksan sebesar 69,40 U/I (Figur 2). Kelompok perlakuan II dan IV menunjukkan rata-rata aktivitas enzim AST serum lebih tinggi dan berbeda nyata $(p<0,05)$ dari kelompok kontrol negatif. Aktivitas enzim AST kelompok perlakuan I tidak berbeda nyata $(p>0,05)$ dari kelompok kontrol negatif. Berbeda dengan kelompok perlakuan III yang aktivitas enzimnya lebih rendah dari kelompok kontrol negatif dan tidak berbeda nyata ( $p>0,05)$. Rata-rata peningkatan aktivitas enzim AST pada kelompok I, II, dan IV secara berturutturut sebesar 29,14, 116,35, dan 90,57\% dibandingkan dengan kelompok kontrol negatif. Kelompok perlakuan terbaik, kelompok perlakuan III dengan rata-rata penurunan aktivitas enzim AST sebesar 3,15\% dibanding kelompok kontrol negatif. Penggunaan dosis angkak dalam campuran yang memberikan hasil terbaik dalam menurunkan kadar enzim ALT dan AST cukup rendah. Hal ini dapat dikarenakan adanya kandungan citrinin yang merupakan zat toksik bagi organ ginjal dan hati yang perlu dipertimbangkan (Wahyuningsih et al., 2019). Campuran angkak dan bekatul dengan penurunan kadar enzim ALT dan AST terbaik adalah campuran III 30:1050 mg/kg BB.

\section{Histopatologi organ}

Analisis histopatologi dalam penelitian ini menggunakan organ hati, pankreas dan ginjal. Organ hati terlibat pada hampir keseluruhan mekanisme metabolisme terutama glukosa darah. Organ pankreas berperan sentral dalam mengontrol glukosa darah melalui sekresi insulin, sedangkan organ ginjal memiliki fungsi ekskresi untuk mengatur keseimbangan cairan dan asam-basa tubuh, termasuk glukosa (Koolman dan Roehm, 2012).

Analisa histopatologi organ menggunakan metode kualitatif dengan mengamati adanya kelainan patologis berupa edema, degenerasi hidropik, degenerasi lemak, nekrosis, dan pendarahan pada setiap organ dan kelompoknya. Edema ditandai dengan pembengkakkan akibat penambahan volume cairan pada rongga kosong organ. Degenerasi hidropik ditandai dengan terjadinya vakuolisasi akibat pemasukan air yang makin meningkat ke dalam sel yang dapat berkembang menjadi degenerasi lemak hingga nekrosis. Degenerasi lemak ditandai dengan adanya vakuola dengan ukuran bervariasi yang dapat mendesak nukleus ke tepi. Nekrosis atau kematian sel ditandai dengan kerusakan inti sel padat dan menghitam (piknosis) serta inti sel terfragmen/ menghilang (karioreksis) akibat kerusakan fatal pada struktur dan fungsi sel secara menyeluruh.

Struktur organ pankreas kelompok kontrol dan kelompok perlakuan ditunjukkan dalam Gambar 1. Pengamatan histopatologi organ pankreas kelompok kontrol normal menunjukkan keadaan organ islet normal dengan gambaran inti sel terlihat sangat padat, tidak tampak nekrosis dan edema. Hal yang berbeda terlihat pada hasil histopatologi kelompok kontrol negatif, terlihat bahwa islet Langerhans mengalami kerusakan, adanya degenerasi hidropik, edema, degenerasi lemak, hingga ditemukannya nekrosis pada organ membuktikan bahwa pemberian aloksan dapat merusak sel endokrin pankreas khususnya sel beta. Profil sel pankreas kelompok kontrol positif terlihat adanya regenerasi selsel termasuk islet Langerhans kembali ke bentuk normal, walaupun masih ditemukan kelainan degenerasi hidropik dibandingkan dengan kelompok kontrol negatif. Pemberian obat glibenklamid mendorong regenerasi sel islet Langerhans (Subashbabu et al., 2014) dan menstimulasi sekresi insulin kembali normal (Ascroft and Rorsman, 2012).

Perubahan organ pankreas pada kelompok perlakuan I, II, dan IV menunjukkan hasil yang kurang baik dibanding kontrol positif, sementara kelompok perlakuan III memberikan hasil yang sama baiknya dengan kontrol positif. Kerusakan pada kelompok perlakuan I, II, IV terlihat berkurang jika dibandingkan dengan kelompok kontrol negatif. Kelainan seperti edema, degenerasi, pendarahan, dan nekrosis masih ditemukan walaupun dengan jumlah yang sedikit. Sementara pada kelompok perlakuan III, kerusakan akibat aloksan hampir semuanya pulih, ditandai dengan keadaan sel yang padat, jarak antar selnya rapat, dan sedikit degenerasi hidropik tanpa ada edema dan nekrosis.

Hasil analisis histopatologi organ hati pada kelompok kontrol normal tidak ditemukan adanya 
kelainan dan struktur selnya menunjukkan gambaran yang baik, yaitu hepatosit berderet secara radier dan membentuk lapisan lobus yang jelas dengan vena sentralis di tengah. Sementara itu, kelainan yang banyak teramati ada pada kelompok kontrol negatif dengan adanya degenerasi hidropik, degenerasi lemak, nekrosis, edema, bahkan pendarahan. Hal ini disebabkan induksi aloksan dapat menyebabkan kerusakan jaringan hati. Pada kelompok kontrol positif hanya tampak adanya edema dan degenerasi lemak skala kecil. Pemberian glibenklamid sebagai kontrol positif dapat berkontribusi mencegah kerusakan hati akibat hiperglikemia, menstimulasi sekresi insulin serta selektif mengurangi katabolisme insulin oleh sel endotel hati (Dwivedi dan Jena, 2018). Gambaran organ yang lebih baik dibandingkan dengan kelompok kontrol negatif dapat ditemukan pada kelompok perlakuan. Kelompok perlakuan I dan II hanya menunjukkan adanya kelainan berupa degenerasi lemak dan pendarahan. Adanya satu jenis kelainan, yaitu degenerasi lemak saja ditemukan pada kelompok perlakuan III dan IV. Hasil dari kelompok perlakuan III dan IV menunjukkan hasil yang sama baik, namun tidak lebih baik dari kelompok positif.

Profil ginjal hasil pengamatan kelompok kontrol normal tidak memiliki kelainan. Profil ginjal normal memperlihatkan bagian korteks yang lebih gelap dari bagian medula, sitoplasma tubulus homogen, berwarna merah muda, dan jernih (Mappa et al., 2013). Organ ginjal kelompok kontrol negatif menunjukkan kerusakan berupa luka atau pendarahan jaringan, pelebaran sel glomerulus, degenerasi dan nekrosis akibat induksi aloksan (Handani et al., 2015). Pada kelompok kontrol positif, kerusakan telah berkurang namun masih teramati beberapa kerusakan seperti degenerasi hidropik, degenerasi lemak, dan pendarahan. Menurut penelitian Mahendran et al. (2011) penggunaan glibenklamid pada organ ginjal yang terinduksi aloksan memiliki potensi memperbaiki struktur sel hingga kembali ke keadaan normal.

Hasil pengamatan organ ginjal kelompok perlakuan secara keseluruhan menunjukkan perubahan struktur sel menjadi lebih baik dibandingkan kelompok kontrol negatif. Beberapa kerusakan yang masih teramati pada kelompok perlakuan adalah degenerasi lemak dan nekrosis. Kerusakan degenerasi lemak dan nekrosis yang tetap ada dapat disebabkan senyawa nefrotoksik yaitu sitrinin pada angkak (Gordon et al., 2010). Akan tetapi, dengan formulasi ekstrak air angkak bekatul (1:1; konsentrasi rendah) sebanyak 30:1050 $\mathrm{mg} / \mathrm{kg}$ BB seperti pada komposisi perlakuan III memberikan hasil yang lebih baik dibandingkan dengan kelompok kontrol positif dengan struktur sel ginjal yang rapat. Keseluruhan kelompok perlakuan ekstrak air angkak bekatul memiliki gambaran profil ginjal yang berbeda jauh dari kontrol negatif yang memberikan gambaran nekrosis struktur sel yang renggang.
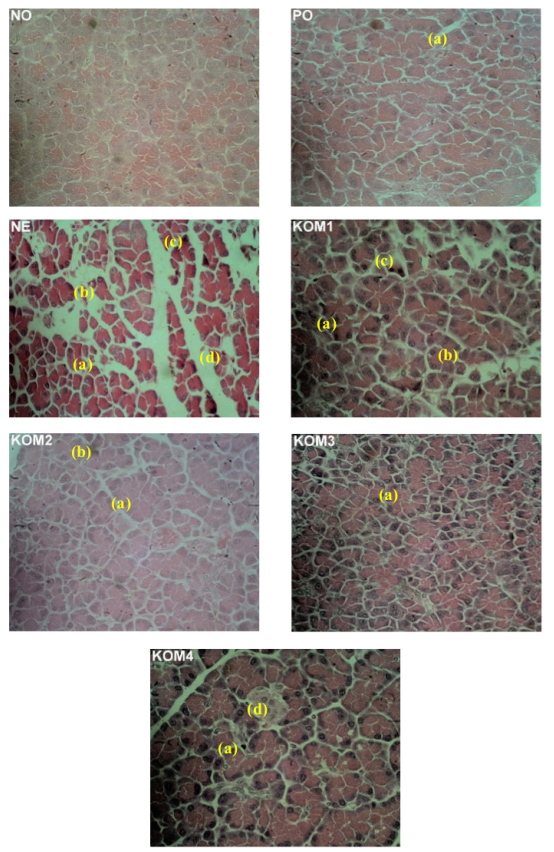

Gambar 1. Histopatologi organ pankreas.

Keterangan: (NO) Kontrol Normal; (PO) Kontrol Positif (a. degenerasi hidropik); (NE) Kontrol Negatif/Aloksan (a, b. edema, c. nekrosis, dan d. degenerasi lemak);

Kelompok 1 (a, b, dan c); Kelompok 2 (a dan e. pendarahan); Kelompok 3 (a); Kelompok 4 (a dan d) dengan perwarnaan HE pada perbesaran $100 \mathrm{x}$.
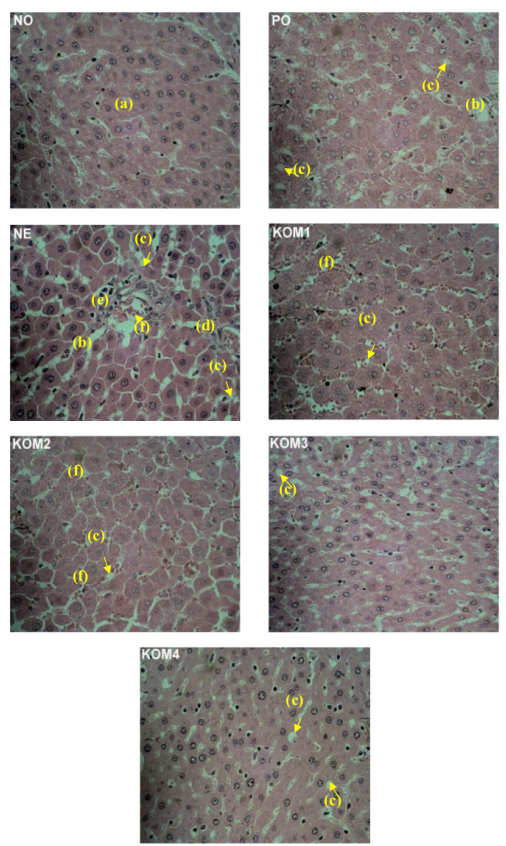

Gambar 2. Histopatologi organ hati. Keterangan: (NO) Kontrol Normal (a. sel hati tersusun radier); (PO) Kontrol Positif (b. edema dan c. degenerasi lemak); (NE) Kontrol Negatif/Aloksan (b, c, d. degenerasi hidropik, e. nekrosis, dan $\mathrm{f}$. pendarahan); Kelompok 1 (c dan f); Kelompok 2 (c dan f); Kelompok 3 (c); Kelompok 4 (c) dengan perwarnaan $\mathrm{HE}$ pada perbesaran 100x.
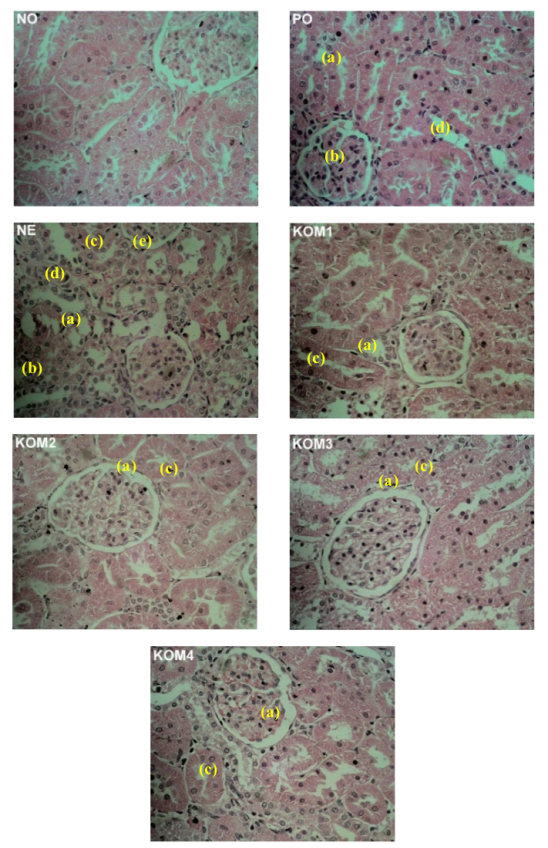

Gambar 3. Histopatologi organ ginjal. Keterangan: (NO) Kontrol Normal; (PO) Kontrol Positif (a. degenerasi lemak, b. pendarahan, dan c. degenerasi hidropik); (NE) Kontrol Negatif/Aloksan (a, b, c, d. nekrosis, dan e. edema); Kelompok 1 (a dan c); Kelompok 2 (a dan c); Kelompok 3 (a dan c); Kelompok 4 (a dan c) dengan perwarnaan HE pada perbesaran 100x. 


\section{Kesimpulan}

Campuran ekstrak angkak dan bekatul terbaik dalam menghambat pembentukan malondialdehyd, menurunkan kadar ALT dan AST adalah kelompok campuran angkak bekatul 30:1050 $\mathrm{mg} / \mathrm{kg}$ BB. Semua campuran angkak dan bekatul dengan berbagai konsentrasi memiliki potensi memperbaiki kerusakan organ pankreas, hati dan ginjal pada tikus hiperglikemik.

\section{Daftar Pustaka}

IFCC [International Federation of Clinical Chemistry]. 1986. Methods for the measurement of catalytic concentration of enzymes. Journal of Clinical Chemistry and Clinical Biochemistry 24:481. PMID: 3734711.

Aalim, H., Belwal, T., Wang, Y., Luo, Z., Hu, J. 2018. Purification and identification of rice bran (Oryza sativa $L$.) phenolic compounds with in-vitro antioxidant and antidiabetic activity using macroporous resins. International Journal of Food Science and Technology 54(3): 715-722. DOI:10.1111/ijfs.13985.

Akihisa, T., Tokuda, H., Yasukawa, K., Ukiya, M., Kiyota, A., Sakamoto, N., Suzuki, T., Tanabe, N., Nishino, H. 2005. Azaphilonces, furanoisophthalides, and amino acids from the extracts of monascus pilosus-fermented rice (red-mold rice) and their chemopreventive effects. Journal of Agricultural and Food Chemistry 53(3): 562-565. DOI:10.1021/jf040199p.

Antula Y., Neno D.S., Arie, S., Chanif, M. 2019. Dietary rice bran plays a significant role in the hepatoprotective effect in hypercholesterolemic rats. The Journal of Experimental Life Science. 9(2): 110-115.

Ashcroft, F., Rorsman P. 2012. Leading edge review: diabetes mellitus and the $\beta$ Cell: the last ten years. Cell 148(6): 1160-1171. DOI: 10.1016/j.cell.2012.02.010

Baskar, A. A.,. Khalid, A., Gabriel, P., Mohammed, A., May, A., Ignacimuthu S. 2012. $\beta$ sitosterol prevents lipid peroxidation and improves antioxidant status and histoarchitecture in rats with 1,2-Dimethylhydrazine induced colon cancer. Journal of Medicinal Food 15(4):335-343. DOI:10.1089/jmf.2011.1780.

Boonloh, K., Kukongviriyapan, U., Pannangpetch, P., Kongyingyoes, B., Senggunprai, L., Prawan, A., Thawornchinsombut, S., Kukongviriyapan, V. 2015. Rice bran protein hydrolysates prevented interleukin-6- and high glucose-induced insulin resistance in hepg2 cells. Food Function 6(2):566-573. DOI: 10.1039/c4fo00872c.

Boue, S., Daigle, K.W., Ming-Hsuan, C., Heping, C., Mark, H.L. 2016. Antidiabetic potential of purple and red rice (Oryza sativa L.) bran extracts. Journal of Agricultural and Food Chemistry 64(26):5345-5353. DOI: 10.1021/acs.jafc. $6 \mathrm{~b} 01909$.

Brouns, F. 2018. Overweight and diabetes prevention: is a low-carbohydrate-high-fat diet recom mendable. European Journal of Nutrition 57:1301-1312. DOI: 10.1007/s00394-018-1636$y$.

Catala, A. 2010. A synopsis of the process of lipid peroxidation since the discovery of the essential fatty acids. Biochemical and Biophysical Research Communications 399 (1): 318-323. DOI: 10.1016/j.bbrc.2010.07.087

Chen, C.C., Liu I., M. 2006. Release of acetylcholine by Hon-Chi to raise insulin secretion in wistar rats. Neuroscience Letter 404(1-2):117-121. DOI: 10.1016/j.neulet.2006.05.024.

Cui, Y., Xingbin, Y., Xinshan L., Jinwen, C., Yan, Z. 2014. Protective effects of polyphenols-enriched extract from Huangshan Maofeng green tea against CCl4-induced liver injury in mice. ChemicoBiological Interactions 220(1):75-83. DOI: 10.1016/j.cbi.2014.06.018.

Dahech I., Belghith, K.S., Hamden, K., Feki, A., Belghith, H., Mejdouba, H. 2011. Oral administration of levan polysaccharide reduces the alloxan-induced oxidative stress in rats. International Journal of Biological Macromolecules 49 (5):942- 947. DOI: 10.1016/j.ijbiomac.2011.08.011.

Damayanthi, E., Kustiyah, L., Khalid, M., Farizal, H. 2010. Aktivitas antioksidan bekatul lebih tinggi dari pada jus tomat dan penurunan aktivitas antioksidan serum setelah intervensi minuman kaya antioksidan. Jurnal Gizi Pangan 5(3):205210. DOI: 10.25182/jgp.2010.5.3.205-210.

Dwivedi, D.K., Jena, G.B. 2018. Glibenclamide protects against thioacetamideinduced hepatic damage in wistar rat: investigation on NLRP3, MMP-2, and stellate cell activation. Naunyn-Schmiedeberg's Archives of Pharmacology 391(11): 1257-1274. DOI: 10.1007/s00210-018-1540-2.

Esterbauer, H., Eckl, P., Ortner, A. 1990. Possible mutagens derived from lipids and lipid precursors. Mutation Research/Reviews in Genetic Toxicology 238(3):223-33. DOI: 10.1016/01651110(90)90014-3.

Esterbauer, H., Schauer, R., Zollner, H. 1991. Chemistry and biochemistry of 4-hydroxynonenal, malonaldehyde and related aldehydes. Free Radical Biology and Medicine 11(1):81-128. DOI: 10.1016/0891-5849(91)90192-6.

Garcia, C.A., Gavino, G., Mosqueda, M., Hevia, P., Gavino, V.C. 2007. Correlation of tocopherol, tocotrienol, $Y$-oryzanol and total polyphenol content in rice bran with different antioxidant capacity assays. Food Chemistry 102(4):12281232. DOI: 10.1016/j.foodchem.2006.07.012.

Giera, M., Lingeman, H., Niessen, W., M., A. 2012. Recent advancements in the LC- and GC-based analysis of malondialdehyde (MDA): a brief overview. Chromatographia 75(9-10):433-40. DOI: 10.1007/s10337-012-2237-1.

Giknis, M., Clifford, C., B. 2008. Clinical Laboratory Parameters for Crl, WI (Han). Charles River, Wilmington, US. 
Gordon, R., Y., Cooperman, T., Obermeyer, W., Becker, D.J. 2010. Marked variability of monacolin levels in commercial red yeast rice products. Archive of Internal Medicine 170(19):1722-1727. DOl: 10.1001/archinternmed.2010.382.

Govindarajan S, Vellingiri K. 2016. Effect of red yeast rice and coconut, rice bran or sunflower oil in rats on hypercholesterolemic diet. Journal of Clinical and Diagnostic Research 10(4). DOI:10.7860/JCDR/ 2016/18623.7624.

Grotto, D., Santa M.,L., Valentini, J., Paniz, C., Schimtt, G., Garcia, S., C., Pomblum, V.,J., Rocha, J.,B., T., Farina, M. 2009. Importance of the lipid peroxidation biomarkers and methodological aspects for malondialdehyde quantifi cation. Química Nova 32(1):169 - 174. DOI: 10.1590/S0100-40422009000100032.

Halliwell, B., Gutteridge, J.,M.,C. 1999. Lipid peroxidation: a radical chain reaction. In: Halliwell, B., Gutteridge, J.M.C. (Eds.), Free radicals in biology and medicine. Page 188-276. Oxford, UK: Clarendon Press.

Handani, A.R., Salim, M.N., Harris, A., Budiman, H., Zainuddin, Sugito. 2015. Pengaruh pemberian kacang panjang (Vigna unguiculata) terhadap struktur mikroskopis ginjal mencit (Mus musculus) yang diinduksi aloksan. Jurnal Medika Veterineria 9(1):18-22. DOI: 10.21157/j.med.vet..v9i1.2987. g2821.

Jaeschke, H. 2010. The mechanism of cell antioxidant defense. In: Roth RA, Ganey P Comprehensive Toxicology, Volume IX: Hepatic Toxicology. Oxford, England: Elsevier.

Jung, C.H., Lee, D.H., Ahn, J., Lee, H., Choi, W.H., Jang, Y.J. 2015.Y-Oryzanol enhances adipocyte differentiation and glucose uptake. Nutrients 7(6):4851-4861. DOI: 10.3390/nu7064851.

Justo, M.L., Rodriguez-Rodriguez, R., Claro, C. M., Alvarez, D.M., Parrado, J., Herrera, M.D. 2013. Water-soluble rice bran enzymatic extract attenuates dyslipidemia, hypertension and insulin resistance in obese zucker rats. European Journal of Nutrition 52(2): 789-797. DOI: 10.1007/s00394012-0385-6.

Kasim, E., Suharna, N., Nurhidayat, N. 2006. Pigment and lovastatin content on the red rice cultivar bah butong and BP 1804 IF 9 which fermented by Monascus purpureus Jmba. Biodiversitas 7(1): 79. DOI:10.13057/biodiv/d070103.

Kaup, R.M., Khayyal, M.T., Verspohl, E.J. 2013. Antidiabetic effects of a standardized egyptian rice bran extract. Phytotheraphy Research 27(2): 264271. DOI: $10.1002 /$ ptr.4705.

Kong, F., Su, Z., Guo, X., Zeng, F., Bi, Y. 2017. Antidiabetic and lipid-lowering effects of the polyphenol extracts from the leaves of clausena lansium (Lour.) skeels on streptozotocin-induced type 2 diabetic rats. Journal of Food Science 83(1): 212-220. doi:10.1111/1750-3841.14004 .

Koolman, J., Roehm, K.H. 2012. Color Atlas of Biochemistry. Thieme, New York (US).
Li, H., Xie Y.H., Yang, Q., Wang S.W., Zhang B.L., Wang J.B., Cao, W., Lin-L.B., Sun, J.Y., Miao, S., Hu, J., Zhou, X., Qiu, P. 2012. Cardioprotective effect of paeonol and danshensu combination on isoproterenol-induced myocardial injury in rats. PLoS ONE 7(11): e48872. DOI:10.1371/journal. pone.0048872

Lykkesfeldt, J. 2007. Malondialdehyde as biomarker of oxidative damage to lipids caused by smoking. Clinica Chemica Acta 380(1):50-58. DOI: 10.1016/j.cca.2007.01.028.

Mahendran, S., Badami, S., Maithili, V. 2011. Evaluation of antidiabetic effect of embelin from Embelia ribes in alloxan induced diabetes in rats. Biomedicine and Preventive Nutrition 1(1):25-31. DOI: 10.1016/j.bionut.2010.08.002.

Mappa, I., S, Kairupan, C., Loho, L. 2013. Gambaran histologi ginjal tikus putih (wistar) setelah pemberian rifampisin. Journal e Biomedik 1(1):338-342. DOI: 10.35790/ebm.1.1.2013.4368.

Masjedia F, Golb A, Dabiric S. 2013. Preventive effect of garlic (Allium sativum L.) on serum biochemical factors and histopathology of pancreas and liver in streptozotocinlnduced diabetic rats. Iranian Journal of Pharmaceutical Research 12 (3): 325338.

Maritim, A. C., Sanders, R.A., Watkins, J.B. 2003. Diabetes, oxidative stress, and antioxidants: a review. Journal Biochemical and Molecular Toxicology 17 (1): 24-38. DOI: 10.1002/jbt.10058.

Matough, F.A., Budin, S.B., Hamid, Z.A., Alwahaibi, N., Mohamed, J. 2012. The role of oxidative stress and antioxidants in diabetic complications. Sultan Qaboos University Medical Journal 12(1)5-18. DOI:10.12816/0003082.

Pasaoglu, H., Sancak, B., Bukan, N. 2004. Lipid peroxidation and resistance to oxidation in patients with type 2 diabetes mellitus. Tohuku Journal Experimental Medicine 203(3): 211-218. DOI:10.1620/tjem.203.211.

Pathel, D.K., Kumar, R., Laloo, D., Hemalatha, S. 2012. Diabetes mellitus: an overview on its pharmacological aspects and reported medicinal plants having antidiabetic activity. Asian Pacific Journal of Tropical Biomedicine 2(5):411-20. DOI: 10.1016/S2221-1691(12)60067-7.

Posuwan, J., Prangthip, P., Leardkamolkarn, V., Yamborisut, U., Surasiang, R., Charoensiri, R., Kongkachuichai, R. 2013. Long-term supplementation of high pigmented rice bran oil (Oryza sativa L.) on amelioration of oxidative stress and histological changes in streptozotocininduced diabetic rats fed a high fat diet; riceberry bran oil. Food Chemistry 138(1):501-508. DOI: 10.1016/j.foodchem.2012.09.144.

Rajasekran A, Kalaivani M, Sabitha R. 2009. Antidiabetic activity of aqueous extract of monascus purpureus fermented rice in high cholesterol diet fed-streptozotocininduced diabetic rats. Asian Journal of Scientific Research 2(4):180-189. DOI: 10.3923/ajsr.2009.180.189. 
Sebai, H., Selmi, S., Rtibi, K., Gharbi, Najoua., Sakly, M. 2014. Protective effect of Lavandula stoechas and Rosmarinus officinalis essential oils against reproductive damage and oxidative stress in alloxan-induced diabetic rats. Journal of Medicinal Food 0(0): 1-9. DOI:10.1089/jmf.2014.0040.

Shi, Y.C, Pan, T.M. 2010. Anti-diabetic effects of Monascus purpureus NTU 568 fermented products on streptozotocin-induced diabetic rats. Journal of Agricultural and Food Chemistry 58(13):7634-7640. DOI:10.1021/jf101194f.

Subashbabu, P., Alshatwi, A., Ignacimuthu, S. 2014. Beneficial antioxidative and antiperoxidative effect of cinnamaldehyde protect streptozotocin-induced pancreatic b-cells damage in wistar Rats. Biomolecules and Therapeutic 22(1):47-54. DOI: 10.4062/biomolther.2013.100.

Tiwari AK, Swapna M, Ayesha SB, Zehra A, Agawane SB, Madhusudana K. 2011. Identification of proglycemic and antihyperglycemic activity in antioxidant rich fraction of some common food grains. International Food Research Journal
18(3):915-923. DOI:10.1111/j.1745-4514.2011. 00547.x.

Wahyuningsih, D., Elyani, H., Sri D.D., Yahya, A., Fadli, M.Z. 2019. Red yeast rice protects hepatocytes conditions of rats receiving high fat diet. Journal of Tropical Life Science 9(2): 171 - 178. DOI: 10.11594/jtls.09.02.06.

Washington, I.M., Hoosier, V.G. 2012. Clinical biochemistry and hematology. Di dalam: The Laboratory Rabbit, Guinea Pig, hamster, and Other Rodents. Suckow MA, Stevens KA, Wilson RP, editor. Academic Pr, London.

Xu, Z., Godber, J.S. 1999. Purification and identification of components of oryzanol in rice bran oil. Journal of Agricultural and Food Chemistry 47:2724-2728. DOI: 10.1021/jf981175j.

Yagi, T. 1987. Differential sensitivities of transformed and untransformed murine cell lines to DNA crosslinking agents relative to repair of O6methylguanine. Mutation Research 184:223-7. DOI:10.1016/0167-8817(87)90020-4. 